ISSN 2078-6441. Вісник Львівського університету. Серія географічна. 2013. Випуск 41. С. 126-131. Visnyk of the Lviv University. Series Geography. 2013. Issue 41. P. 126-131.

338.91

\author{
т лія ністрянськ, иросл в ністрянський \\ ьвівський н ціон льний університет імені в н \\ вул. . орошенк , 41, 79000, м. ввів, кр їн
}

озкрито сутність поняття дуже м лих міських поселень. ро н лізов но скл д цієї к тегорії н селених пунктів в кр їні. изн чено геогр фічні особливості поширення з регіон ми кр їни дуже м лих міських поселень т сх р ктеризов но їхній демогр фічний потенці л. бгрунтов но місце дуже м лих міських поселень у перспективній системі розселення кр їни.

лючові слов : дуже м ле міське поселення, дуже м ле місто, селище міського типу, систем розселення, дміністр тивний ст тус поселень.

еогр фія поселень кр їни, як і більшості кр їн світу, є територі льною основою життєдіяльності всього суспільств . собливо це стосується великих і середніх міст, які є основними осередк ми політичного, економічного т культурного життя держ в, центр ми обслуговув ння всієї прилеглої місцевості. одноч с процеси з селення, освоєння т соці льного розвитку більшої ч стини території кр їни безпосередньо пов'яз ні з функціонув нням м лих міських поселень, середовище яких формується двом тип ми н селених пунктів - м лими міст ми і селищ ми міського типу. еред м лих міст кр їни особливу групу ст новлять дуже м лі міст, людністю до 10 тис. осіб, що, згідно з чинними укр їнськими норм тивними документ ми [2], н віть не відповід є критеріям міст. кі дуже м лі міст $i$ з демогр фічним $m$ соці льно-економічним потенці лом, $i$ з внутрішньою територі льною структурою дуже подібні до селищ міського типу, тому ці дві групи н селених пунктів доцільно об'єдн ти в одну к тегорію дуже м лих міських поселень. Зн чимо, що т ке об'єдн ння є доцільним лише для зручності суспільно-геогр фічного н лізу і водноч с недоцільним у пр ктиці дміністр тивно-територі льних відносин, тобто в контексті н д ння цим груп м поселень якогось одного окремого ст тусу, н прикл д ст тусу містечк, як передб чено в деяких проект х дміністр тивно-територі льної реформи [1], оскільки це з свідчило 6 і зниження теперішнього ст тусу т нег тивно позн чилось 6 н соці льному розвитку дуже м лих міст.

уже м лі міські поселення з г лом зосереджують сьогодні доволі зн чну ч стку н селення кр їни з г лом $(15,6 \%)$ т ьвівської обл. зокрем $(16,7 \%)$. стк дуже м лих міст від з г льної кількості міст кр їни ст новить $21 \%$. огляду н зн чне поширення дуже м лих міських поселень, особливо селищ, їхній людський т культурно-туристичний потенці ли, т кож викон ння функцій лок льних центрів в обслуговув нні сільської місцевості, ця к тегорія поселень з безпечує в жливі міжпоселенські функції, будучи одним з чинників зб л нсув ння всієї поселенської мережі т ст біліз ції демогеогр фічної ситу ції у відд лених місцевостях.

(C) ністрянськ ., ністрянський ., 2013 
одноч с питом в г дуже м лих міських поселень в економічному потенці лі держ ви т регіонів є зн чно меншою, що пов'яз но з нег тивними тенденціями суч сного економічного розвитку. ільшість з дуже м лих міських поселень потерп є від недост тності з собів виробництв т інвестицій, тому м є депресивний х $\mathrm{p}$ ктер, що в сукупності робить особливо кту льним пит ння прогнозув ння їхніх под льших перспектив т й з г лом - моделюв ння оптим льних співвідношень у системі розселення.

ля вирішення б г то спектної проблем тики функціонув ння т под льшої тр нсформ ції цієї к тегорії поселень потрібні зусилля ф хівців різного профілю, у тому числі й геогр фів. дн к в н лізі цієї проблем тики укр їнськими геогр ф ми помітною є певн методологічн однобічність, зумовлен домінув нням у суч сній суспільній геогр фії п р дигми систем розселення, як, попри безз перечні здобутки, все ж бсолютизує рівень вз ємопов'яз ності комп ктно розт шов них поселень, тр ктуючи їх як н логи фізичних систем, яким н чебто вл стиві всі з кони системної орг ніз ції. огляду н це у дослідженні розселення н селення конструктивним може бути пок тегорійний підхід, який ми ре лізув ли і який передб ч є виділення поселень однієї к тегорії в окремий об'єкт дослідження з для визн чення всієї сукупності природних т соці льних чинників їхнього функціонув ння т 3 г льної ролі в територі льній орг ніз ції розселення. ей підхід передб ч $€$ н ліз поселень певної к тегорії в меж х великого регіону порівняно з ситу цією в інших регіон х т у з г льнон ціон льному м сшт бі.

гідно з пок тегорійним підходом вивчення особливостей розміщення т демогр фічної зн чущості дуже м лих міських поселень є першочерговим ет пом їхнього всебічного дослідження і передб ч є порівняльний регіон льний н ліз кількості й густоти селищ т дуже м лих міст, визн чення ч сток н селення цих груп поселень у структурі міського н селення. озр хунки всіх цих пок зників у з г льнон ціон льному м сшт бі т н прикл ді одного регіону, виявлення з лежностей між ними 3 допомогою кореляційного н лізу д ють підст ви для висновків про з г льні тенденції поширення цих груп поселень.

структурі дуже м лих міських поселень в жливе зн чення м ють селищ міського типу: ч стк н селення селищ у міському н селенні ст новить 13,2 \%, водноч с ч стк н селення дуже м лих міст - лише 2,4\% (див. т блицю). поч ток 2011 р. в кр їні офіційно було 885 селищ міського типу і 95 дуже м лих міст. йбільш кількість селищ зосереджен н онеччині: 131 у онецькій обл. (15\% від їхньої з г льної кількості) і 109 - у уг нській (12\%). обто с ме в онецькому м крогеогр фічному регіоні зосереджено більше чверті всіх селищ кр їни. ост тньо зн чною є і суч сн мереж селищ міського типу ьвівської обл., яку формують 34 поселення, що ст новить 3,8 \% від усіх селищ кр їни.

сновним пок зником, який розкрив є суттєві регіон льні відмінності поширення селищ, є їхя густот, як з лежить від різних чинників - рівнів урб нізов ності й індустрі льного розвитку, густоти н селення з г лом, історико-геогр фічних передумов. цьому спекті високою густотою селищної мережі виділяється н с мперед онеччин ( онецьк т уг нськ обл сті), що пов'яз но з особливостями формув ння поселенської мережі в процесі розвитку промисловості, головно добувної, рківськ обл., де особливо помітним є гломер ційний вплив дуже великого міст , т кож рим, де суттєве зн чення м ло формув ння приморських селищ ун слідок розвитку рекре ційного господ рств . певний зв'язок (хоч й не тісний) між ч сткою міського н селення 
т густотою селищ (коефіцієнт кореляції ст новить 0,56). одноч с зн чення коефіцієнт кореляції між густотою н селення і густотою селищ дорівнює 0,69 ; це свідчить про те, що густот селищ порівняно більше детермінов н густотою н селення з г лом. цьому контексті середня густот селищ у г лицьких регіон х $(1,51$ селищ н 1 тис. км²) $\epsilon$ дещо вищою, ніж у середньому по кр їні $(1,47)$, т кож у більшості регіонів ентр льної, івнічної т івденної кр їни (з винятком риму) головно з вдяки порівняно високій густоті селищ в но- $р$ нківської обл. $(1,73)$, як $є$ н йвищою серед 3 хідноукр їнських регіонів. кщо високу густоту селищ онеччини ( онецької т

уг нської обл стей) пояснюють високим рівнем індустрі льного розвитку т урб нізов ності, які неухильно вели до формув ння споч тку робітничих селищ, потім і селищ міського типу т міст, то порівняно висок густот селищ г лицьких обл стей м є історично-геогр фічні передумови (д вність з селення, інтенсивність іноетнічної колоніз ції впродовж середніх віків, широкий розвиток тогоч сних ремесел і торгівлі, поширення м гдебурзького пр в $\mathrm{T}$ iн.), що з г лом посприяло н ближенню структури міського розселення з хідних обл стей кр їни з центр льноєвропейськими кр їн ми. обто у формув нні густоти селищ г лицьких обл стей рівень їхньої урб нізов ності не є визн ч льним чинником, оскільки ч стк міського н селення в цих регіон х менш , ніж у середньому по кр їні.

крім онеччини, рим, рківської обл. т прик рп тських г лицьких обл стей, н більшій ч стині території кр їни густот селищ є меншою, ніж у середньому по держ ві. йменш густот поселень цієї к тегорії х р ктерн для икол ївської, олт вської т ерк ської обл стей.

ише ч стково відповід є густоті селищ демогр фічне зн чення цієї к тегорії поселень у міському н селенні, шо пов'яз но 3 різним рівнем урб нізов ності регіонів і розвитком міст. прикл д, н йбільш ч стк селищного н селення в структурі міського н селення х р ктерн для н йменш урб нізов ної к рп тської обл., хоч густот селищ у цьому регіоні є приблизно н середньодерж вному рівні. одноч с через високий рівень урб нізов ності онецької обл. ч стк селищного н селення в міському н селенні цього регіону є меншою, ніж у середньому по кр їні, хоч с ме цей регіон м є н йвищу густоту селищ. зом із к рп тською обл. групу регіонів з високою ч сткою селищного н селення в структурі міського н селення формують ерсонськ , итомирськ , іровогр дськ обл сті, де розвиток мережі міст є порівняно нижчим від середньоукр їнських пок зників.

езв ж ючи н зн чну кількість селищ, н йменш ч стк селищного н селення х р ктерн с ме для ьвівської обл., що зумовлено невеликою середньою людністю селищ т зн чною кількістю міст. сусідній в но- $p$ нківській обл. ч стк н селення селищ у з г льній кількості міського н селення $(19,7 \%) \in$ зн чно вищою через нижчий рівень урб ніз ції цього регіону т меншу демогр фічну в гу обл сного центру. одноч с н явність великих т дуже великих міст зумовлює м лу демогр фічну в гу селищного н селення і у ніпропетровській т порізькій обл стях.

ількість дуже м лих міст у пон д дев'ять р зів менш, ніж селищ. е н слідок різних чинників, одн к н с мперед - регуляторної дії норм тивних документів, згідно 3 якими людність міст кр їни не повинн бути менше 10 тис. осіб. дн к, незв ж ючи н т кі обмеження, у більшості регіонів кр їни т кі міст все ж тр пляються. иняток ст новлять ніпропетровськ, икол ївськ, ерсонськ т мельницьк обл сті, де дуже м лих міст зовсім нем . ернівецькій т ернопільській обл стях с ме дуже м лі міст ст новлять основу міського розселення регіонів, у ьвівській обл. їхня 
кількість дорівнює половині всіх міст. е у двох з хідноукр їнських регіон х - в но$\mathrm{p}$ нківській т к рп тській обл стях - кількість дуже м лих міст перевищує третину від усіх поселень цієї к тегорії. ідповідно, і густот дуже м лих міст є н йвищою у ьвівській, ернівецькій, ернопільській т в но- $\mathrm{p}$ нківській обл стях (див. т блицю). стк н селення дуже м лих міст у структурі н селення цих регіонів колив ється від 9,2\% у ьвівській обл. до 16,3\% у ернівецькій.

егіон льні відмінності поширення в кр їні селищ міського типу т дуже м лих міст

\begin{tabular}{|c|c|c|c|c|c|c|c|}
\hline $\begin{array}{c}\text { кр їн }, \\
\text { втономія, } \\
\text { обл сті }\end{array}$ & $\begin{array}{c}\text { ількість } \\
\text { селищ } \\
\text { міського } \\
\text { типу }\end{array}$ & $\begin{array}{c}\text { устот } \\
\text { селищ } \\
\text { міського } \\
\text { типу } \\
\text { (кількість } \\
\text { н } 1 \text { тис. } \\
\text { км²) }^{2}\end{array}$ & $\begin{array}{c}\text { стк } \\
\text { н селен- } \\
\text { ня селищ } \\
\text { міського } \\
\text { типу в } \\
\text { міському } \\
\text { н селен- } \\
\text { ні, \% } \\
\end{array}$ & $\begin{array}{l}\text { ількість } \\
\text { дуже } \\
\text { м лих } \\
\text { міст }\end{array}$ & \begin{tabular}{|c} 
устот \\
дуже \\
м лих \\
міст \\
(кількість \\
н 1 тис. \\
км²) $^{2}$
\end{tabular} & $\begin{array}{c}\text { стк } \\
\text { н селення } \\
\text { дуже м - } \\
\text { лих міст у } \\
\text { міському } \\
\text { н селенні, } \\
\%\end{array}$ & $\begin{array}{c}\text { стк н - } \\
\text { селення всіх } \\
\text { дуже м лих } \\
\text { міських } \\
\text { поселень у } \\
\text { міському } \\
\text { н селенні, } \\
\% \\
\end{array}$ \\
\hline кр їн & 885 & 1,47 & 13,2 & 95 & 0,16 & 2,4 & 15,6 \\
\hline рим & 56 & 2,15 & 16,2 & 2 & 0,08 & 1,9 & 18,1 \\
\hline інницьк & 29 & 1,09 & 19,1 & 2 & 0,08 & 2,3 & 21,4 \\
\hline олинськ & 22 & 1,09 & 18,0 & 3 & 0,15 & 3,0 & 21,0 \\
\hline ніпропетровськ & 46 & 1,44 & 8,6 & - & - & - & 8,6 \\
\hline онецьк & 131 & 4,94 & 10,6 & 5 & 0,19 & 1,0 & 11,6 \\
\hline итомирськ & 43 & 1,44 & 24,0 & 1 & 0.03 & 1,6 & 25,6 \\
\hline к рп тсьК & 19 & 1,48 & 29,3 & 4 & 0,31 & 9,8 & 39,1 \\
\hline порізьк & 23 & 0,85 & 8,3 & 1 & 0,04 & 0,6 & 8,9 \\
\hline в но- $\mathrm{p}$ нківсьК & 24 & 1,73 & 19,8 & 7 & 0,50 & 12,0 & 31,8 \\
\hline иївськ & 30 & 1,07 & 22,3 & 3 & 0,10 & 0,9 & 23,2 \\
\hline іровогр дськ & 26 & 1,06 & 20,7 & 2 & 0,08 & 3,2 & 23,9 \\
\hline уГ НсьК & 109 & 4.08 & 18,0 & 7 & 0,26 & 2,9 & 20,9 \\
\hline ьвівсьК & 34 & 1,38 & 7,5 & 22 & 1,01 & 9,2 & 16,7 \\
\hline икол ївськ & 17 & 0,69 & 13,9 & - & - & - & 13,9 \\
\hline деськ & 33 & 0,99 & 11,2 & 4 & 0,12 & 2,5 & 13,7 \\
\hline олт всьК & 21 & 0,73 & 12,6 & 1 & 0,03 & 1,1 & 13,7 \\
\hline івненськ & 16 & 0,80 & 18,1 & 2 & 0,10 & 3,6 & 21,7 \\
\hline умськ & 20 & 0,84 & 10,6 & 4 & 0,17 & 4,2 & 14,8 \\
\hline ернопільськ & 17 & 1,23 & 17,8 & 10 & 0.72 & 16,2 & 34,0 \\
\hline рківськ & 61 & 1,94 & 16,3 & 2 & 0,06 & 0,9 & 17,2 \\
\hline ерсонськ & 30 & 1,05 & 24,5 & - & - & - & 24,5 \\
\hline мельницьк & 24 & 1,17 & 13,7 & - & - & - & 13,7 \\
\hline ерк сьК & 15 & 0,72 & 9,3 & 2 & 0,10 & 2,9 & 12,2 \\
\hline ернівецьк & 8 & 0.99 & 15,2 & 8 & 0,99 & 16,3 & 31,5 \\
\hline ернігівськ & 30 & 0,94 & 17,6 & 3 & 0,09 & 3,0 & 20,6 \\
\hline
\end{tabular}

ьвівськ обл. виділяється не лише н йбільшою кількістю дуже м лих міст (22), й н явністю ж восьми міст ( елз, ібрк, линяни, обромиль, ом рно, овий линів, гнів, ирів) людністю до 5 тис. осіб. ут є і н йменше місто кр їни - гнів (1,0 тис. осіб н поч ток 2011 р.). ке широке розміщення дуже м лих міст у 3 хідно- 
укр їнських регіон х зумовлене суттєвими історико-геогр фічними відмінностями формув ння мережі розселення н селення, тому н віть у р дянські ч си вв ж ли недоцільним поширюв ти н міські поселення цих регіонів офіційні норм тивні критерії (щодо людності, з йнятості т ін.). кі особливості міського розселення з хідних обл стей кр їни треб вр хув ти й у н ступних нових укр їнських 3 кон х, щоб не спричинити зниження міського ст тусу низки поселень.

меж ми хідної кр їни дещо більшу густоту дуже м лих міст м ють онецьк , уг нськ, умськ т деськ обл сті. відміну від історично зумовлених з хідноукр їнських дуже м лих міст, н явність відповідних поселень у промислових східних регіон х є перев жно н слідком критичного зниження їхньої людності в ост нні десятиліття через депресивний економічний х р ктер. огляду н невисоку густоту дуже м лих міст центр льної, східної т південної ч стин кр їни їхня ч стк в структурі усього міського н селення тут не перевищує $4,5 \%$.

енші регіон льні відхилення простежуються у сум рних зн ченнях ч сток усіх дуже м лих поселень (тобто і селищ, і дуже м лих міст) у структурі міського н селення. йбільше посл блення демогр фічної в ги дуже м лих міських поселень х р ктерне для ніпропетровської т порізької обл стей, де основу міського н селення формують великі т дуже великі міст . евисокою є ч стк дуже м лих міських поселень і у онецькій обл. (див. т блицю). одноч с у б г тьох менш урб нізов них регіон х сум рн ч стк н селення селищ т дуже м лих міст ст новить пон д п'яту ч стину всього міського н селення. крім з хідноукр їнських регіонів, це х р ктерно для інницької, итомирської, иївської, іровогр дської т ернігівської обл стей.

тже, дуже м лі міські поселення є об’єктивним моментом в освоєнні території т окремою, в жливою і необхідною к тегорією поселень, як слугує з'єднув льною л нкою міського т сільського розселення, будучи одним із чинників зб л нсув ння всієї поселенської мережі т ст біліз ції демогеогр фічної ситу ції у відд лених місцевостях. рост ння депресивності розвитку дуже м лих міських поселень, яке н мітилося ост нніми рок ми, - це з гроз поглиблення диспропорцій у розселенні н селення, погіршення ситу ції з обслуговув нням сільської місцевості, відповідно, і збільшення з гроз нег тивного перебігу демогр фічних процесів. ому проблем ктивіз ції ролі м лих міських поселень (і м лих міст, і селищ) потребує глибокого концепту льного осмислення проблеми т створення необхідних економічних і політичних передумов пр ктичної ре ліз ції. концепту льному спекті в жливо зрозуміти, що под льші процеси соці льно-політичного т економічного розвитку, урб ніз ції т тр нсформ ції структури розселення повинні пройти не в н прямі неухильної концентр ції виробництв , соці льно-культурної інфр структури т інвестицій у н йбільших і великих міст х, у н прямі змішення всього політичного, економічного т соці льно-культурного життя вглиб кр їни, до середніх, м лих і дуже м лих міст.

\section{СПИСОК ВИКОРИСТАНОЇ ЛІТЕРАТУРИ}

1. еформ для людини. бірник м тері лів про шляхи ре ліз ції дміністр тивнотериторі льної реформи в кр їні. - . : екрет рі т бінету іністрів кр їни, 2005. $-238 \mathrm{c}$. 
2. к 3 резидії ерховної ди від 12 березня 1981 року “ ро порядок вирішення пит нь дміністр тивно-територі льного устрою кр їнської " // ідомості . . 1981. - № 12. - . 177-180.

m ття: н дійшл до ред киії 29.08.2012

доопр иьов н 14.12.2012

прийнят до друку 20.02.2013

\title{
VERY SMALL URBAN SETTLEMENTS OF UKRAINE: REGIONAL FEATURES OF SPREAD AND DEMOGRAPHIC VALUE
}

\author{
Natalia Dnistryanska, Myroslav Dnistryanskyy \\ Ivan Franko National University of Lviv, \\ P. Doroshenko St., 41, UA - 79000 Lviv, Ukraine
}

Essence of concept of very small urban settlements was given. The content of this category of settlements in Ukraine was analyzed. The geographical features of distribution of small towns by region of Ukraine were defined and their demographic potential was described. The place of very small settlements in the prospective settlement system of Ukraine was substantiated.

Key words: very small urban settlements, a small town, urban village, settlement system, the administrative status of the settlements.

\section{т лия нистрянск я, иросл в нистрянский}

\author{
ьвовский н цион льный университет имени в н \\ ул. . орошенко, 41, 79000, г. ввов, кр ин
}

скрыто сущность понятия очень м лых городских поселений. ро н лизиров но сост в этой к тегории н селенных пунктов в кр ине. пределено геогр фические особенности р спростр нения по регион м кр ины очень м лых городских поселений и ох р ктеризов но их демогр фический потенци л. боснов но место очень м лых городских поселений в перспективной системе р сселения кр ины.

лючевые слов : очень м лое городское поселение, очень м ленький город, поселок городского тип, систем р сселения, дминистр тивный ст тус поселений. 